\title{
Influence of Thermally Oxidized Vegetable Oil and Animal Fats on Growth Performance, Nutrient Digestibility, Carcass Parameters and Meat Quality of Broilers
}

Original Article

EAuthor(s)

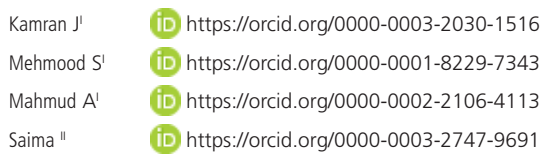

Department of Poultry Production, University of Veterinary and Animal Sciences, Lahore, Pakistan.

Department of Animal Nutrition, University of Veterinary and Animal Sciences, Lahore, Pakistan.

\section{Mail Address}

Corresponding author e-mail address Shahid Mehmood

Department of Poultry Production, University of Veterinary and Animal Sciences, Lahore, Pakistan.

Phone: +92-332-4522310

Email: shahid.mehmood@uvas.edu.pk

\section{- Keywords}

Oxidized soy oil, fresh soy oil, poultry refined oil, growth, digestibility, broilers.

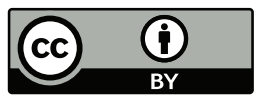

Submitted: 16/January/2020 Approved: 19/April/2020

\section{ABSTRACT}

The current study was planned to investigate the influence of soy oil, oxidized soy oil, poultry oil single refined and poultry oil double refined on the performance of broilers chicken. A total of two hundred and forty, day-old broiler chicks were divided into 4 treatments in such a way that each treatment had six replicates and each replicate had ten chicks. The experimental treatments were separated with the usage of single refined poultry oil, double refined poultry oil, oxidized soy oil and soy oil in the diet of broilers. In both starter and overall periods average body weight was higher $(p<0.05)$ for birds which were on a basal diet containing soy oil as compared to other diets. Similarly, feed intake was higher $(p<0.05)$ for birds which were on a basal diet containing soy oil in the starter phase. In the overall phase, average body weight was less in oxidized oil as compared to other dietary treatments $(p<0.05)$. Similarly, birds showed poor feed conversion ratio in the basal diet that contained oxidized oil $(p<0.05)$ in the overall phase of the experiment. The birds showed better digestibility $(p<0.05)$ for crude fat on a basal diet containing vegetable oil and double refined poultry oil as compared to other diets. Results showed no effects of experimental treatments on the meat quality and carcass parameters ( $p>0.05$ ). Therefore, it can be concluded that poultry single refined and double refined oil could be a possible substitute for fresh soy oil for better performance as compared to oxidized soy oil.

\section{INTRODUCTION}

In commercial broiler diets, vegetable oils and animal fats are being used to increase the energy density of the diet and to improve the growth rate and feed efficiency of broilers (Blanch et al., 1996; Tavárez et al., 2011; Zhang et al., 2011). Among available oil sources for broilers feed, vegetable oils are rich in polyunsaturated fatty acids and are highly digestible for broilers. However, polyunsaturated fatty acids are highly sensitive towards oxidation during storage that could be detrimental for the growth and health of broilers (Jakobsen et al., Børsting et al., 1994; 1993; Engberg et al., 1996; Anjum et al., 2004; Tan et al., 2018; Tan et al., 2018; Yang et al., 2019).

A lot of work has been done to evaluate the effect of oxidized oil on the broiler production, however, the results of oxidized oils on the broiler production are conflicting (Jakobsen et al., Børsting et al., 1994; 1993; Engberg et al., 1996; Anjum et al., 2004; Tan et al., 2018; Tan et al., 2018; Yang et al., 2019). Oertel \& Hartfiel (1982) reported that the addition of oxidized soybean oil @ 7\% in the diet of broilers had no effect on feed intake, weight gain, and feed conversion ratio (FCR) of growing broilers. However, Jakobsen et al.,1993 and Lin et al.,1989 reported that oxidized fat in the diet of broilers had a negative influence on the performance and health of broilers. It has been reported that 
negative effect of oxidized fat sources in the diet of broilers on performance is due to the rancidity of feed, reduction in palatability and less feed intake (Lin et al., 1989; Jakobsen et al., 1993). It has also been reported that oxidized fat sources in the diet of the broiler decrease digestibility and lead to poor performance of the broilers (Børsting et al., 1994; Hussein \& Kratzer 1982)

Variable results of addition of oxidized oil in the diet of broiler on the performance of broilers depend upon the source of fat, degree of oxidation and conditions that caused the oxidation of fats. It has been reported that fat origin and the oxidation condition of fat (e.g., extent of temperature, time of heating, presence of oxygen and catalysts, and water activity) effect differently on the performance of the broilers when included in the diet of broilers (Lin et al., 1989; Engberg et al., 1996; Anjum et al., 2004; Yang et al., 2019). Gopalakrishna \& Prabhakar (1986) reported that the origin of fats and the condition of oxidation of fats results in production of a significant amount of oxidation products. A large number of these oxidative products are not considered to have any toxic effect however, some of these oxidative products are supposed to have toxic properties that have potential to damage the brush border membrane of the intestine (Kimura et al., 1984) and liver (Kazuki et al., 1986; Engberg et al., 1996). Therefore, the inclusion of fat in the diet of poultry birds not only affects animal growth but also negatively influences the health of growing birds (Kimura et al., 1984; Kazuki et al., 1986; Engberg et al., 1996). Recently, it has been reported that digestive tract health is important for better growth (Qiu et al., 2019a; Qiu et al., 2019b). Furthermore, the inclusion of oxidized oils in the diet of broilers influences the quality of broiler meat and meat products (Lin et al., 1989). Deterioration of meat quality due to oxidized oil in the diet of broiler may reduce the consumption of poultry meat because broiler meat is regularly selected over other meats due to low lipid contents and relatively higher concentration of polyunsaturated fatty acids (Nkukwana et al., 2014; Yang et al., 2019).

Poultry industry is trying to find suitable substitute of common soybean oil, corn oil and oxidized vegetable oil (Yang et al., 2019). The problem of oxidation of vegetable oil during storage, the increasing price of vegetable oil and the decreasing availability of common vegetable fat sources are encouraging broiler producers to look for alternative oil sources. Keeping in mind the need for broiler industry, research was planned to evaluate the effect of poultry oil (single refined and double refined), oxidized soy oil and soy oil on feed intake, growth, digestibility, meat quality, and carcass parameters. In the current study, influence of soy oil, oxidized soy oil, poultry oil single refined and poultry oil double refined on feed intake, growth, digestibility, meat quality, and carcass parameters were investigated. The birds were fed diets providing fresh soy oil, oxidized soy oil, poultry oil single refined and poultry oil double refined respectively.

\section{MATERIAL AND METHODS}

\section{Experimental design, animal husbandry, and experimental diets}

The current research was executed in a completely randomized experimental design (CRD). The experimental treatments were single refined poultry oil, double refined poultry oil, oxidized soy oil and soy oil.

A total of two hundred and forty, broiler chicks (1 day-old) were procured from a local hatchery in Pakistan. Chicks were distributed into four experimental treatments in such a way that each experimental treatment had six replicates and each replicate had ten chicks. The total experimental duration for the current study was 35 days. Flushing was done with the help of sugar solution ( $1 \mathrm{~kg}$ sugar $/ 5 \mathrm{~L}$ water) on the first day of the experiment. The temperature of brooding was set at $95^{\circ} \mathrm{F}$ for the first week. The temperature was decreased by $5^{\circ} \mathrm{F}$ every week until it reached $75^{\circ} \mathrm{F}$. During the experimental period, ad libitum feed and water were ensured to all experimental birds. Broiler vaccination schedule was practiced according to the suggestion of a local veterinarian. The experimental diets were corn-soybean based and formulated to meet or exceed the nutrient requirement of growing broiler as recommended by Cobb500. The diet composition was standard as set by Wildlife Administration of Pakistan (Tiwana et al., 2019). All the ingredients for the formulation of the feed were provided by a local commercial feed mill (Five Star Feeds Pvt. Ltd. Gujranwala, Pakistan). All diets were formulated on digestible amino acids (AA) basis keeping lysine as reference $A A$ as described in a recent study (Abdullah et al., 2019). The experiment was divided into three dietary phases that were starter phase, grower phase and finisher phase as shown in table 1. The starter dietary phase took place in the first 10 days. The grower dietary phase were from days 11-22 while the finisher dietary phase were from days 23-35. The experimental protocol was approved by the synopsis committee 
Table 1 - Composition of experimental basal diets.

\begin{tabular}{|c|c|c|c|c|c|c|c|c|c|c|c|c|}
\hline \multicolumn{5}{|c|}{ Starter (Day 1-10) } & \multicolumn{4}{|c|}{ Grower (Day 11-22) } & \multicolumn{4}{|c|}{ Finisher (Day 23-35) } \\
\hline Ingredient (\%) & Soy oil & $\begin{array}{l}\text { Poultry } \\
\text { Fat(S) }\end{array}$ & $\begin{array}{l}\text { Poultry } \\
\text { Fat(D) }\end{array}$ & $\begin{array}{l}\text { Oxidized } \\
\text { oil }\end{array}$ & Soy oil & $\begin{array}{l}\text { Poultry } \\
\text { Fat(S) }\end{array}$ & $\begin{array}{l}\text { Poultry } \\
\text { Fat(D) }\end{array}$ & $\begin{array}{l}\text { Oxidised } \\
\text { oil }\end{array}$ & Soy oil & $\begin{array}{l}\text { Poultry } \\
\text { Fat(S) }\end{array}$ & $\begin{array}{l}\text { Poultry } \\
\text { Fat(D) }\end{array}$ & $\begin{array}{c}\text { Oxidised } \\
\text { oil }\end{array}$ \\
\hline Corn & 54.6 & 54.71 & 54.71 & 54.71 & 60.03 & 60.75 & 60.75 & 60.75 & 64.09 & 64.72 & 64.72 & 64.72 \\
\hline Soybean Meal & 29.72 & 29.7 & 29.7 & 29.7 & 27.06 & 27.11 & 27.11 & 27.11 & 20.77 & 20.88 & 20.88 & 20.88 \\
\hline Rice Polish & 4 & 4 & 4 & 4 & 3.74 & 2.96 & 2.96 & 2.96 & 2.435 & 1.788 & 1.788 & 1.788 \\
\hline Canola meal & 4 & 4 & 4 & 4 & 0 & & & & 1.91 & 1.81 & 1.81 & 1.81 \\
\hline Fish Meal & 0 & 0 & 0 & 0 & 3 & 3 & 3 & 3 & 5.5 & 5.5 & 5.5 & 5.5 \\
\hline soy oil & 3 & 0 & 0 & 0 & 3 & 0 & 0 & 0 & 3 & 0 & 0 & 0 \\
\hline Poultry Fat(S) & 0 & 3 & 0 & 0 & 0 & 3 & 3 & 3 & 0 & 3 & 0 & 0 \\
\hline Poultry Fat(D) & 0 & 0 & 3 & 0 & 0 & 0 & 0 & 0 & 0 & 0 & 3 & 0 \\
\hline Oxidised Oil & 0 & 0 & 0 & 3 & 0 & 0 & 0 & 0 & 0 & 0 & 0 & 3 \\
\hline L-Lysine SO4 & 0.609 & 0.61 & 0.61 & 0.61 & 0.461 & 0.462 & 0.462 & 0.462 & 0.374 & 0.375 & 0.375 & 0.375 \\
\hline DL-Methionine & 0.377 & 0.376 & 0.376 & 0.376 & 0.321 & 0.321 & 0.321 & 0.321 & 0.26 & 0.26 & 0.26 & 0.26 \\
\hline L-Threonine & 0.209 & 0.209 & 0.209 & 0.209 & 0.15 & 0.15 & 0.15 & 0.15 & 0.102 & 0.103 & 0.103 & 0.103 \\
\hline Salt & 0.539 & 0.535 & 0.535 & 0.535 & 0.293 & 0.296 & 0.296 & 0.296 & 0.237 & 0.238 & 0.238 & 0.238 \\
\hline $\mathrm{CaCo} 3$ & 1.277 & 1.286 & 1.286 & 1.286 & 1.14 & 1.133 & 1.133 & 1.133 & 0.931 & 0.93 & 0.93 & 0.93 \\
\hline Arginine & 0.115 & 0.115 & 0.115 & 0.115 & 0.055 & 0.058 & 0.058 & 0.058 & 0.04 & 0.041 & 0.041 & 0.041 \\
\hline $\begin{array}{l}\text { Monocalcium } \\
\text { phosphate }\end{array}$ & 1.394 & 1.299 & 1.299 & 1.299 & 0.59 & 0.6 & 0.6 & 0.6 & 0.191 & 0.195 & 0.195 & 0.195 \\
\hline $\begin{array}{l}\text { Phytase(10,000 } \\
\text { FTU) }\end{array}$ & 0.01 & 0.01 & 0.01 & 0.01 & 0.01 & 0.01 & 0.01 & 0.01 & 0.01 & 0.01 & 0.01 & 0.01 \\
\hline $\begin{array}{l}\text { Vitamin/Min } \\
\text { premix/Emulsifier }\end{array}$ & 0.15 & 0.15 & 0.15 & 0.15 & 0.15 & 0.15 & 0.15 & 0.15 & 0.15 & 0.15 & 0.15 & 0.15 \\
\hline Total & 100 & 100 & 100 & 100 & 100 & 100 & 100 & 100 & 100 & 100 & 100 & 100 \\
\hline $\mathrm{EE} \%$ & 5.89 & 5.9 & 5.9 & 5.9 & 6.3 & 6.2 & 6.2 & 6.2 & 6.45 & 6.37 & 6.37 & 6.37 \\
\hline СР\% & 21 & 21 & 21 & 21 & 20 & 20 & 20 & 20 & 19 & 19 & 19 & 19 \\
\hline $\mathrm{AME}, \mathrm{kcal} / \mathrm{kg}$ & 3,000 & 3,000 & 3,000 & 3,000 & 3,100 & 3,100 & 3,100 & 3,100 & 3,150 & 3,150 & 3,150 & 3,150 \\
\hline Calcium, \% & 0.96 & 0.96 & 0.96 & 0.96 & 0.87 & 0.87 & 0.87 & 0.87 & 0.8 & 0.8 & 0.8 & 0.8 \\
\hline Available P, \% & 0.48 & 0.48 & 0.48 & 0.48 & 0.43 & 0.43 & 0.43 & 0.43 & 0.4 & 0.4 & 0.4 & 0.4 \\
\hline Sodium, \% & 0.23 & 0.23 & 0.23 & 0.23 & 0.16 & 0.16 & 0.16 & 0.16 & 0.16 & 0.16 & 0.16 & 0.16 \\
\hline Digestible Lys, \% & 1.28 & 1.28 & 1.28 & 1.28 & 1.15 & 1.15 & 1.15 & 1.15 & 1.03 & 1.03 & 1.03 & 1.03 \\
\hline Digestible Met, \% & 0.65 & 0.65 & 0.65 & 0.65 & 0.602 & 0.602 & 0.602 & 0.602 & 0.55 & 0.55 & 0.55 & 0.55 \\
\hline $\begin{array}{l}\text { Digestible Met + } \\
\text { Cys, \% }\end{array}$ & 0.95 & 0.95 & 0.95 & 0.95 & 0.87 & 0.87 & 0.87 & 0.87 & 0.8 & 0.8 & 0.8 & 0.8 \\
\hline Digestible Thr, \% & 0.86 & 0.86 & 0.86 & 0.86 & 0.77 & 0.77 & 0.77 & 0.77 & 0.69 & 0.69 & 0.69 & 0.69 \\
\hline Digestible Arg, \% & 1.37 & 1.37 & 1.37 & 1.37 & 1.23 & 1.23 & 1.23 & 1.23 & 1.1 & 1.1 & 1.1 & 1.1 \\
\hline
\end{tabular}

University of Veterinary and Animal Sciences (UVAS), Lahore. Experimental procedures were followed by the guidelines and code of practice of UVAS, Lahore. Permission for all experiment procedures were granted by the ethical approval committee of UVAS, Lahore. The birds were ensured free from hunger and thirst as described in previous researches (Aziz ur Rahman et al., 2017; Aziz ur Rahman et al., 2019).

\section{Performance parameters}

To measure the feed intake, growth rate and performance parameters standard procedures were adopted as presented in the recent study (Hussain et al., 2018; Hussain et al., 2020). In brief, the birds were weighed at days 1, 21 and 35 of the experiment.
Weekly feed intake was calculated, body weight gain and feed intake were recorded for the overall period.

\section{Fecal samples}

From days 33 to 35, fecal samples were collected from each pen by total collection method as described in the literature. In brief, a plastic sheet was spread in each pen before the start of the digestibility trial. After every $24 \mathrm{~h}$, total feces were collected from each pen carefully. Contaminants such as scales, feathers, down, straws, and other fine dust particles were removed. The collected samples were packed in sample bags (sealed plastic bags). Standard scientific approaches were adopted to seal the sample as described in literature to avoid any sample loss (lamam-ul-Haq et 
al., 2019; Shahzad et al., 2019). Sealed plastic sample bags were stored at $-30{ }^{\circ} \mathrm{C}$ in the refrigerator until further analysis. Furthermore, collected samples were grounded in a grinder having $0.5-\mathrm{mm}$ sieve. Grounded samples were further analyzed for chemical analysis as described in recent studies (Chen et al., 2019; He et al., 2018; Su et al., 2013).

\section{Nutrient digestibilities determination}

For determination of digestibilities of nutrients, collected feed and fecal samples were analyzed for dry matter and crude fat determination. Dry matter and crude fat were determined using the protocol of AOAC (1995) as described in previous studies (Muhammad et al., 2016; Niu et al., 2017; Xia et al., 2018). The resulting values were used to calculate the DM and crude fat digestiblities as described in the recent study.

\section{Carcass and meat quality parameters determination}

Carcass parameter was determined following the procedure of Sharif et al. (2018). For the determination of carcass and meat quality parameters standard procedures were followed as described in the literature. In brief, two broilers were arbitrarily selected from each replicate within a treatment to measure live BW at day 35 of the trial. After slaughtering and depluming of feathers, head, viscera, and shanks were separated. Then portioning of the carcass was done to obtain the weight of the breast, legs, live weight, carcass weight, thigh meat yield, and breast meat yield. Similarly, meat obtained was used for meat quality parameters determination.

\section{Statistical analysis}

Collected data were analyzed to check the significance of the treatments by using the standard statistical procedures. In brief, data were subjected to ANOVA using the GLM procedure of SAS. Differences between means were identified using Duncan's multiple range test. Differences were considered significant at $p<0.05$.

\section{Growth performance}

Results for growth performance are shown in table 2. Results revealed that oxidation of soy oil and fat

Table 2 - Effect of oxidized vegetable oil and animal fats addition in broiler diets on performance of broiler.

\begin{tabular}{|c|c|c|c|c|c|c|}
\hline & \multicolumn{3}{|c|}{$0-21$ days } & \multicolumn{3}{|c|}{$0-35$ days } \\
\hline & ${ }^{1}$ Avg. BW & Feed intake & ${ }^{2} \mathrm{FCR}$ & Avg. BW & Feed intake & FCR \\
\hline Used Oil & $808.17^{b}$ & $1000.70^{a b}$ & 1.24 & $2011^{c}$ & 3500 & $1.74^{\mathrm{a}}$ \\
\hline Poultry Double & $827.83^{a b}$ & $1004.50^{\mathrm{ab}}$ & 1.22 & $2164.70^{a}$ & 3585.20 & $1.66^{b}$ \\
\hline Poultry Single & $807.00^{b}$ & $984.83^{b}$ & 1.22 & $2106.20^{a}$ & 3496.70 & $1.66^{b}$ \\
\hline Soy Oil & $860.33^{a}$ & $1032.30^{\mathrm{a}}$ & 1.20 & $2157^{a}$ & 3525 & $1.63^{b}$ \\
\hline$p$ value & 0.0068 & 0.0548 & 0.4082 & $<0.0001$ & 0.1088 & 0.0032 \\
\hline${ }^{3} \mathrm{SE}$ & 10.698 & 11.405 & 0.0158 & 18.855 & 27.045 & 0.0184 \\
\hline
\end{tabular}

${ }^{1}$ Average body weight

${ }^{2}$ Feed conversion ratio

${ }^{3} \mathrm{SE}$; standard error

Means with different superscripts in a column differ significantly $(p<0.05)$

sources affected feed intake, and average weight gain $(p<0.05)$ in the starter phase of the experimental period. However, FCR was not affected by dietary treatment ( $p>0.05)$ in starter phase of the experiment. While in overall phase average weight and FCR were influenced by oxidation of soy oil and fat sources $(p<0.05)$ but feed intake was similar in all experimental treatments $(p>0.05)$. Average body weight was high $(p<0.05)$ for birds which were on a basal diet containing soy oil as compared to other diets in the starter phase of the experiment. Similarly, feed intake was higher $(p<0.05)$ for the birds which were on a basal diet containing soy oil as compared to other diets in the starter phase. In the overall phase, average body weight was less in oxidized oil as compared to other dietary treatments $(p<0.05)$. Similarly, birds showed poor FCR in the basal diet that contained oxidized oil as compared to other dietary treatments $(p<0.05)$ in the overall phase of the experiment. However, in the overall phase feed intake was similar in all the experimental treatments $(p>0.05)$.

\section{Nutrient digestibility}

The results of nutrient digestibility are shown in table 3 . The results revealed that the experimental treatments affected the fat digestibility of the diet $(p<0.05)$. The birds showed better digestibility $(p<0.05)$ for crude fat on a basal diet containing vegetable oil and double refined poultry oil as compared to other diets. However, in the current study the experimental treatments did not have effect on dry matter and nitrogen digestibilities $(p<0.05)$. 
Table 3 - Effect of oxidized vegetable oil and animal fats addition on nutrient digestibility of broilers.

\begin{tabular}{lccc}
\hline & Fat & Dry matter & Nitrogen \\
\hline Used Oil & $70.74^{\mathrm{c}}$ & 70.11 & 70.77 \\
Poultry Double & $78.16^{\mathrm{a}}$ & 71.05 & 71.97 \\
Poultry Single & $73.61^{\mathrm{b}}$ & 70.62 & 71.68 \\
Soy Oil & $80.57^{\mathrm{a}}$ & 72.03 & 72.14 \\
p value & $<0.0001$ & 0.2406 & 0.9056 \\
${ }^{1}$ SE & 0.5392 & 0.6230 & 1.4317 \\
\hline
\end{tabular}

'SE; standard error

Means with different superscripts in a column differ significantly $(p<0.05)$

\section{Carcass and meat quality parameters}

The results of carcass and meat quality parameters are presented in table 4 . Results showed no effects of experimental treatments on the carcass parameters ( $p>0.05)$. Similarly, the results showed no effects of experimental treatments on the quality parameters of meat $(p>0.05)$

\section{DISCUSSION}

Prices of poultry feeds are increasing in developing countries due to higher prices of macro ingredients (corn and soybean) which contribute to a major portion of the feed. Sousa Lima et al., 2016), reported that the prices of most utilized raw materials for the formulation of diet fluctuates and it is vital to find the substitute of conventional ingredients especially corn and soybean to reduce the feed costs. Keeping in view the need for feed industry, different scientists are working on different alternative ingredients for poultry to reduce the cost of feed (Tan et al., 2018; Yang et al., 2019) and oxidized oils are one of them. The use of oxidized oil in the diet of broiler chicks (Ehr et al., 2015), weaned pigs (Li et al., 2012), and different aquatic animals (Lewis-McCrea \& Lall 2007; Dong et al., 2011) represents that it could be potential alternative feed ingredients.

However, the addition of oxidized oil in the diet of animal's influence performance variably. (Dong et al.,
2011; Tavárez et al., 2011; Wang et al., 2015). Tavárez et al., 2011 reported that the addition of oxidized oils in the diet of broilers impaired the performance of broilers. Similarly, Wang et al. (2015) also reported that the addition of oxidized oil in broiler diets negatively influence the broilers performance. Contrary to the results of Tavárez et al., 2011, and Wang et al., 2015, no negative effects have been reported by Dong et al., 2011 on broilers performance by using oxidizing oils in the broiler diet. Contradiction in the performance results by using oxidizing oil in the diet of birds could be explained by the theory of Yue et al. (2010) and Zhang et al. (2010) who reported that the oxidizing oil inclusion rate and the degree of oil oxidation are the major factors which influences the animal's performance. In our study, no significant effects of feeding diets containing soy oil, and poultry double refined oils were observed on average body weight, intake and starter phase. However, feeding oxidized soy oil in the diet of broiler reduced average body weight and intake as compared to fresh soy oil and poultry double refined oil. The findings of the intake are similar to the studies of Hussein \& Kratzer (1982) who reported less feed intake in rancid broiler fed experimental diets with high peroxide value. In contrary to the findings of the current study, Diaz (1977) reported similar feed intake in experimental broilers fed experimental feed with oxidized fat/oil with or without added antioxidant. Similar to the findings of Diaz (1977), L'estrange et al. (1966) also stated that the inclusion of oxidized beef tallow in the diet of broiler had no negative effect on the feed intake of the broiler birds as compared to the control. Similarly, Chae et al. (2002) also stated that broiler chicks fed the experimental diet which contained fresh or oxidized soybean oil showed no difference in feed intake. Contradiction in the results of performance by using oxidizing oil in the diet of the birds could be explained by the theory of Yue et al., 2010 and Zhang et al., 2010 who reported that oxidizing oil inclusion rate and degree of oil oxidation are the major factors which

Table 4 - Effect of oxidized vegetable oil and animal fats addition in the diet of broilers on meat quality.

\begin{tabular}{|c|c|c|c|c|c|c|}
\hline & Chroma & HUE & Lightness & Redness & Yellowness & $\mathrm{pH}$ \\
\hline Used Oil & 27.03 & 59.23 & 50.66 & 13.37 & 22.35 & 6.05 \\
\hline Poultry Double & 26.56 & 58.62 & 51.41 & 13.06 & 23.58 & 6.08 \\
\hline Poultry Single & 26.86 & 57.06 & 52.42 & 13.14 & 22.42 & 6.02 \\
\hline Soy Oil & 27.39 & 59.97 & 52.56 & 12.87 & 24.75 & 6.10 \\
\hline$p$ value & 0.95 & 0.8118 & 0.7174 & 0.8674 & 0.3335 & 0.6042 \\
\hline SE & 1.0190 & 2.1859 & 1.3349 & 0.4193 & 1.0321 & 0.0484 \\
\hline
\end{tabular}

'SE; standard error

Means with different superscripts in a column differ significantly $(p<0.05)$ 
Table 5 - Effect of oxidized vegetable oil and animal fats addition in the diet of broilers on carcass parameter.

\begin{tabular}{|c|c|c|c|c|c|}
\hline & Breast \% & Dressing \% & Fat $\%$ & Liver & Thigh \\
\hline Used Oil & 33.76 & 64.58 & 2.41 & 2.87 & 5.20 \\
\hline Poultry Double & 33.76 & 63.99 & 2.13 & 2.68 & 5.32 \\
\hline Poultry Single & 35.21 & 64.75 & 2.64 & 2.71 & 5.41 \\
\hline Soy Oil & 34.58 & 65.22 & 2.76 & 2.91 & 5.30 \\
\hline$p$ value & 0.329 & 0.3349 & 0.5786 & 0.4966 & 0.9319 \\
\hline SE & 0.6376 & 0.4626 & 0.3399 & 0.1257 & 0.2232 \\
\hline
\end{tabular}

ISE; standard error

Means with different superscripts in a column differ significantly $(p<0.05)$

influences the animal's performance. In our study, it could be suggested that less degree of rancidity was the reason for similar feed intake in the overall period of the experiment. However, less weight gain in birds on oxidized soy oil could be supported by the findings of Chae et al. (2002) who stated that lower weight gain in chicks was observed when the birds were fed experimental ration which contained rancid rice polish as compared to the fresh rice polish. The reduction of weight gain in broiler on feed containing oxidized soy oil might be due to devastation of fat-soluble vitamins in rancid oil that leads to decreased availability of nutrients as well as immunity, and subsequently, reduce the growth performance (Lin et al., 1989). Findings of higher weight gain with fresh soy oil feed are similar to the results of Anjum et al., (2004) who reported the highest weight gain in chicks fed fresh soy oil than those fed oxidized soy oil which indicates that feed containing oxidized soybean oil is of poor quality. However, in the overall phase, interesting results were observed where average body weight and FCR were similar in birds fed diets containing poultry single refined oil, poultry double refined oil and fresh soy oil diet. Therefore, it could be assumed that poultry single refined and double refined could be a possible substitute of fresh soy oil for better performance as compared to oxidized soy oil.

The reduced weight gain and FCR in birds fed experimental diets which contained oxidized oil could be explained by the theory of Waheed et al., (2004) who reported that thiobarbituric acid values for fats in fat ingredients increased during the oxidation process of fats which have a negative influence on chick's growth and FCR. Furthermore, feeding of oxidized fats to birds results in lower retention of fat and energy in birds, which showed by the reduced capability of fat digestion (Chae et al., 2002; Engberg et al., 1996). Moreover, a higher growth rate in fresh soy oil could also be supported by higher fat digestion as compared to oxidized oil.
Oxidized soybean oil, poultry single refined and double refined oil in the diet of broiler did not affect dressing percentage and weights of internal organs (liver). Findings of dressing percentage are similar with the findings of Anjum et al. (2004) who reported that oxidized soybean oil had no effect on dressing percentage and weights of internal organs (liver). Results of dressing percentages are quite comparable to those reported in other studies (Diaz, 1977; Hussein \& Kratzer, 1982).

Similar to carcass parameters oxidized soybean oil, poultry single refined and double refined oil in the diet of broiler did not affect meat chroma, hue, lightness, redness, yellowness, and $\mathrm{pH}$. Findings of meat chroma, hue, lightness, redness, yellowness, and $\mathrm{pH}$ are similar with the findings of (Anjum et al., 2004) who reported that meat chroma, hue, lightness, redness, yellowness and $\mathrm{pH}$ are not influenced by fresh or oxidized oil.

\section{CONCLUSION}

Based on the findings of intake, growth, digestibility, carcass, and meat quality parameters it is concluded that the use of oxidized soy oil in the diet of broilers negatively influences intake, growth, digestibility of fat and feed conversion ratio. Therefore, it is recommended that poultry single refined and double refined oil could be a possible substitute for fresh soy oil for optimum broiler growth.

\section{REFERENCES}

Abdullah, HM, Bielke LR, Helmy YA. Effect of arginine supplementation on growth performance and immunity of broilers: a review. Journal of Global Innovation in Agricultural and Social Sciences 2019;7(4):141144.

Anjum M, Mirza I, Khan A, Azim A. Effect of fresh versus oxidized soybean oil on growth performance, organs weights and meat quality of broiler chicks. Pakistan Vetetrinary Journal 2004;24(4):173-178.

Aziz ur Rahman M, Chuanqi X, Huawei S, Binghai C. Effects of hay grass level and its physical form (full length vs. chopped) on standing time, drinking time, and social behavior of calves. Journal of Veterinary Behavior: Clinical Applications and Research 2017;21(Suppl C):7-12. 
Aziz ur Rahman M, Xia C, Ji L, Cao B, Su H. Nutrient intake, feeding patterns, and abnormal behavior of growing bulls fed different concentrate levels and a single fiber source (corn stover silage). Journal of Veterinary Behavior: Clinical Applications and Research 2019;33:46-53.

Blanch A, Barroeta A, Baucells M, Serrano X, Puchal F. Utilization of different fats and oils by adult chickens as a source of energy, lipid and fatty acids. Animal Feed Science and Technology 1996;61(1-4):335-342.

Børsting CF, Engberg RM, Jakobsen K, Jensen SK, Andersen JO. Inclusion of oxidized fish oil in mink diets 1 . The influence on nutrient digestibility and fatty-acid accumulation in tissues. Journal of Animal Physiology and Animal Nutrition 1994;72(1-5):132-145.

Chen Dong CY, Zhen H, Xiao K, Tang J, Tang Q, Muhammad AR. Effects of replacing whole-plant corn silage with whole-plant rice silage and rice straw on growth performance, apparent digestibility and plasma parameters in growing angus cross bred beef cattle. Internationl Journal of Agriculture and Biology 2019;(22):1116-1122.

Chae $B$, Lee $K$, Lee $S$. Effects of feeding rancid rice bran on growth performance and chicken meat quality in broiler chicks. AsianAustralas. Journal of Animal Sciences 2002;15(2):266-273.

Diaz R. Effect of including rancid fats in rations for meat chickens. Nutrition Abstract and Review 1977;49(6):2385

Dong X, Lei W, Zhu X, Han D, Yang Y, Xie S. Effects of dietary oxidized fish oil on growth performance and skin colour of Chinese longsnout catfish (Leiocassis longirostris Günther). Aquaculture Nutrition $2011 ; 17(4): e 861-e 868$

He Y, Niu W, Qiu Q, Xia C, Shao T, Wang H, et al. Effect of calcium salt of long-chain fatty acids and alfalfa supplementation on performance of Holstein bulls. Oncotarget 2018;9(3):3029.

Ehr I, Kerr B, Persia M. Effects of peroxidized corn oil on performance, AMEn, and abdominal fat pad weight in broiler chicks. Poultry Science 2015;94(7):1629-1634.

Engberg RM, Lauridsen C, Jensen SK, Jakobsen K. Inclusion of oxidized vegetable oil in broiler diets. Its influence on nutrient balance and on the antioxidative status of broilers. Poultry Science 1996;75(8):10031011.

Gopalakrishna A, Prabhakar J. Effect of water activity on autoxidation of methyl linoleate. Journal of Food Science and Technology 1986;23(3):152-157.

Hussain M, Mahmud A, Hussain J, Qaisrani S, Mehmood S, Rehman A. Subsequent effect of dietary lysine regimens fed in the starter phase on the growth performance, carcass traits and meat chemical composition of aseel chicken in the grower phase. Brazilian Journal of Poultry Science 2018;20:455-462.

Hussain M, Mahmud A, Hussain J, Qaisrani SN, Mehmood S, Ahmad S, et al. Effect of dietary amino acid regimens on growth performance and bodyconformation and immune responses in Aseel chicken. Indian Journal of Animal Research 2020;54(1):53-58.

Hussein AS, Kratzer F. Effect of rancidity on the feeding value of rice bran for chickens. Poultry Science 1982;61(12):2450-2455.

lamam-ul-Haq, Naeem MS, Amir RM, llyas M, Shabir F, Ahmad I, et al. Growth and yield response of spring maize (zea mays I.) Under different potassium doses and irrigation regimes. Journal of Global Innovation in Agricultural and Social Sciences 2019;7(3):135-139.

Shahzad M, Ghani WH, Ayyub M, Ali Q, Ahmad HM, Faisal M, et al. Performance of some wheat cultivars against aphid and its damage on yield and photosynthesis. Journal of Global Innovation in Agricultural and Social Sciences 2019;7(3):105-109.
Jakobsen K, Engberg RM, Hartfiel W. The biological activity of natural source tocopherols in chickens fed fresh or oxidized fat rich in linoleic acid. Archives of Animal Nutrition 1993;44(4):339-355.

Kazuki K, Hitoshi A, Shinsuke M, Masato N. The effect of orally administered secondary autoxidation products of linoleic acid on the activity of detoxifying enzymes in the rat liver. Biochimica et Biophysica Acta (BBA)-Lipids and Lipid Metabolism 1986;879(1):36-43.

Kimura T, lida K, Takei Y. Mechanisms of adverse effect of air-oxidized soy bean oil-feeding in rats. Journal of Nutritional Sciences and Vitaminology 1984;30(2):125-133.

L'estrange J, Carpenter K, Lea C, Parr L. Nutritional effects of autoxidized fats in animal diets: 2. Beef fat in the diet of broiler chicks. British Journal of Nutrition 1966;20(1):113-122.

Lewis-McCrea LM, Lall SP. Effects of moderately oxidized dietary lipid and the role of vitamin $\mathrm{E}$ on the development of skeletal abnormalities in juvenile Atlantic halibut (Hippoglossus hippoglossus). Aquaculture 2007;262(1):142-155

Li P, Piao X, Ru Y, Han X, Xue L, Zhang H. Effects of adding essential oil to the diet of weaned pigs on performance, nutrient utilization, immune response and intestinal health. Asian-Australasian Journal of Animal Sciences 2012;25(11):1617

Lin C, Asghar A, Gray J, Buckley D, Booren A, Crackel R, et al. Effects of oxidised dietary oil and antioxidant supplementation on broiler growth and meat stability. British Poultry Science 1989;30(4):855-864.

Muhammad AU, Xia CQ, Cao BH. Dietary forage concentration and particle size affect sorting, feeding behaviour, intake and growth of Chinese holstein male calves. Journal of Animal Physiology and Animal Nutrition 2016;100(2):217-223

Niu W, He Y, Xia C, Rahman MAU, Qiu Q, Shao T, et al. Effects of replacing Leymus chinensis with whole-crop wheat hay on Holstein bull apparent digestibility, plasma parameters, rumen fermentation, and microbiota. Scientific Reports 2017;7(1):1-12.

Nkukwana TT, Muchenje V, Masika P, Hoffman LC, Dzama K, Descalzo AM. Fatty acid composition and oxidative stability of breast meat from broiler chickens supplemented with Moringa oleifera leaf meal over a period of refrigeration. Food Chemistry 2014;142:255-261.

Oertel M, Hartfiel W. Effect of fresh and oxidized fats/oils and proand antioxidants on the growth of broiler chicks [Archiv fuer Gefluegelkunde]. Stuttgart: Verlag Eugen Ulmer; 1982.

Qiu Q, Gao C, Gao Z, He Y, Cao B, Su H. Temporal Dynamics in rumen bacterial community composition of finishing steers during an adaptation period of three months. Microorganisms 2019a;7(10):410.

Qiu Q, Zhu Y, Qiu X, Gao C, Wang J, Wang H, et al. Dynamic variations in fecal bacterial community and fermentation profile of Holstein steers in response to three stepwise density diets. Animals 2019b;9(8):560.

Shahzad M, Ghani WH, Ayyub M, Ali Q, Ahmad HM, Faisal M, et al. Performance of some wheat cultivars against aphid and its damage on yield and photosynthesis. Journal of Global Innovation in Agricultural and Social Sciences 2019;7(3):105-109.

Sharif M, Shoaib M, Rahman MAU, Ahmad F, Rehman SU. Effect of distillery yeast sludge on growth performance, nutrient digestibility and slaughter parameters in Japanese quails. Scientific Reports 2018;8(1):16.

Sousa Lima VB de, Dourado LRB, Machado LP, Biagiotti D, Lima SBP de, Campos Ferreira GJB de. Cottonseed oil in diets for broilers in the prestarter and starter phases. PLoS ONE 2016;11(1):e0147695. 


\section{Broilers}

Su H, Wang Y, Zhang Q, Wang F, Cao Z, Rahman MAU. Responses of energy balance, physiology, and production for transition dairy cows fed with a low-energy prepartum diet during hot season. Tropical Animal Health and Production. 2013;45(7):1495-1503.

Tan L, Rong D, Yang Y, Zhang B. The Effect of oxidized fish oils on growth performance, oxidative status, and intestinal barrier function in broiler chickens. The Journal of Applied Poultry Research 2018;28(1):31-41.

Tan L, Rong D, Yang Y, Zhang B. Effect of oxidized soybean oils on oxidative status and intestinal barrier function in broiler chickens. Brazilian Journal of Poultry Science 2018;20:333-342.

Tavárez M, Boler DD, Bess K, Zhao J, Yan F, Dilger A, et al. Effect of antioxidant inclusion and oil quality on broiler performance, meat quality, and lipid oxidation. Poultry Science 2011;90(4):922-930.

Tiwana U, Hafeez S, Ahmad HM, Habib R. Diet composition of a wildlife species in agri-ecosystems of faisalabad, punjab, pakistan. Journal of Global Innovation in Agricultural and Social Sciences 2019;7(2):73-78.

Waheed A, Ahmad T, Yousaf A, Zaefr I. Effect of various levels of fat and antioxidant on the quality of broiler rations stored at high temperature for different periods. Pakistan Veterinary Journal 2004;24(2):70-75.

Wang L, Li E, Qin J, Du Z, Yu N, Kong Y, et al. Effect of oxidized fish oil and $\alpha$-tocopherol on growth, antioxidation status, serum immune enzyme activity and resistance to $A$ eromonas hydrophila challenge of $C$ hinese mitten crab E riocheir sinensis. Aquaculture Nutrition 2015;21(4):414424.

Yang A, Qi M, Wang X, Wang S, Sun L, Qi D, et al. Refined cottonseed oil as a replacement for soybean oil in broiler diet. Food science \& Nutrition 2019;7(3):1027-1034.

Yue H, Zhang L, Wu S, Xu L, Zhang H, Qi G. Effects of transport stress on blood metabolism, glycolytic potential, and meat quality in meat-type yellow-feathered chickens. Poultry Science 2010;89(3):413-419.

Xia C, Liang Y, Bai S, He Y, Muhammad AUR, Su H, et al. Effects of harvest time and added molasses on nutritional content, ensiling characteristics and in vitro degradation of whole crop wheat. Asian-Australasian Jouranal of Animal Science 2018;31(3):354-362.

Zhang B, Haitao L, Zhao D, Guo Y, Barri A. Effect of fat type and lysophosphatidylcholine addition to broiler diets on performance, apparent digestibility of fatty acids, and apparent metabolizable energy content. Animal Feed Science and Technology 2011;163(2):177-184.

Zhang W, Xiao S, Lee EJ, Ahn DU. Consumption of oxidized oil increases oxidative stress in broilers and affects the quality of breast meat. Journal of Agricultural Food Chemistry 2010;59(3):969-974. 